\title{
TIMING OF JUDICIAL REVIEW UNDER THE ADMINISTRATIVE PROCEDURE ACT
}

Before the adoption of the Administrative Procedure Act (APA), ${ }^{\prime}$ the question often arose as to whether courts could review an administrative action in the absence of any statutory provision for review. American School of Magnetic Healing v. McAnnulty ${ }^{2}$ established the common law rule that the courts do not need congressional authorization to review administrative actions. It is equally clear, however, that acts of a given agency are unreviewable to the extent that a statute expressly or implicitly precludes judicial review of the agency's action ${ }^{3}$ and to the extent that the action sought to be reviewed is committed solely to the agency's discretion. ${ }^{4}$ Finally, even if a given action is subject to judicial review, the courts will withhold review until the dispute is "ripe."

The judicial review provisions of the $\mathrm{APA}^{6}$ incorporate these common law limitations on the judicial review of administrative actions. This Comment will discuss the timing of judicial review under the APA in the light of three recent cases: Abbott Laboratories $v$. Gardner, ${ }^{7}$ Toilet Goods Association v. Gardner ${ }^{8}$ and Gardner v. Toilet Goods Association. ${ }^{9}$ It will consider the standard for implying preclusions of review, the ripeness doctrine, and their relation to each other. This Comment will not discuss the third limitation on review-the nonavailability of judicial review of matters which are committed to

1. The APA was adopted in 1946. Ch. 324,60 Stat. 237.

2. 187 U.S. 94 (1902). The Supreme Court held that the district court had jurisdiction to review a decision of the Postmaster General to deprive the plaintiff of the use of the mails for the conduct of his business. The Court declared that acts of "officers must be justified by some law, and in case an official violates the law to the injury of an individual the courts generally have jurisdiction to grant relief." Id. at 108.

3. See, e.g. Schilling v. Rogers, 363 U.S. 666 (1960) (express preciusion); Switchmen's Union v. National Meditation Bd., 320 U.S. 297 (1943) (implied preclusion).

4. See, e.g.. Panama Canal Co. v. Grace Line, Inc., 356 U.S. 309, $317-19$ (1958); Eberlein v. United States, 257 U.S. 82 (1921); Nishimura Ekiu v. United States, 142 U.S. 651,660 (1892); Ferry v. Udall, 336 F.2d 706 (9th Cir. 1964), cert. denied, 381 U.S. 904 (1965).

5. Generally the older cases do not speak of ripeness, but ask whether the administrative action sought to be reviewed is an "order" or a "final order." See, e.g.. Columbia Broadcasting Sys. v. United States, 316 U.S. 407 (1942); Rochester Tel. Corp. v. United States, 307 U.S. 125 (1939); United States v. Los Angeles \& S.L.R.R., 273 U.S. 299 (1927). See generally 3 K. Davis, Administrative Law Treatise ch. 21 (1958); L. Jaffe, Judicial Control of AdminiSTRATIVE ACTION ch. 10 (1965).

6. Section 10, 5 U.S.C. $\$ \S 701-06$ (Supp. 11, 1967).

7. 387 U.S. 136 (1967).

8. 387 U.S. 158 (1967).

9. 387 U.S. 167 (1967). 
agency discretion-since this involves the problem of review vel non, rather than the timing of review. ${ }^{10}$

\section{STANDARDS OF PRECLUSION}

The introductory clause of section 10 of the APA provides that the judicial review provisions of the Act are not applicable "to the extent that-(1) statutes preclude judicial review; or (2) agency action is committed to agency discretion by law." "The distinction between an action which is unreviewable because it is committed to agency discretion by law and an action which is unreviewable because a statute precludes review is often hazy and sometimes nonexistent. To the extent that a statute completely precludes review of an agency action, the agency will be left to its own discretion. Often, however, it is admitted that the dispute between the plaintiff and the agency presents issues which are subject to judicial scrutiny at some stage, but it is argued that a statute precludes review of the dispute at the stage which the plaintiff wishes to obtain it. In such a case, a finding that the statute precludes review is not a declaration that the agency action is committed to agency discretion, but merely that Congress has restricted the availability of review to a particular stage of the administrative process. This determination is made completely independently of the common law ripeness doctrine, which would normally control the availability of review at a given stage of the administrative process. ${ }^{2}$ When a court finds that a statute precludes judicial review at a particular stage, it simply rules that review must be temporarily denied, no matter how "ripe" the particular action before the court may be.

Since postponement of review may seriously harm or disadvantage a party, the ease or difficulty with which the courts imply such partial preclusions of review is of considerable importance. Yet no uniform guidelines have been developed for determining whether particular statutory language dictates postponement of judicial review in a given situation. An examination of a number of immigration and food and drug cases which have arisen under the APA illustrates that the courts

10. A preclusion of review may, of course, also raise the problem of review vel non. Compare Boire v. Greyhound Corp., 376 U.S. 473, $481-82$ (1964), with Leedom v. Kyne, 358 U.S. 184, 189 90 (1958). On unreviewable actions generally see 4 K. Davis, AdMINISTRATIVE LAW Treatise ch. 28 (1958). The concern of this Comment is with preclusions which go to the timing of review. See text accompanying notes $11-12$ infra.

11. 5 U.S.C. $\$ 701$ (a) (Supp. 11, 1967).

12. See text accompanying notes 88-89 infra for an explanation of the ripeness doctrine. 
have relied upon varying and often inconsistent standards in making this determination.

\section{A. The Immigration Cases}

In Heikkila v. Barber, ${ }^{13}$ the Attorney General had ordered Heikkila's deportation pursuant to section 22 of the Internal Security Act of $1950,{ }^{14}$ which made membership in the Communist Party per se a ground for deportation. Heikkila sought a declaratory judgment that the statute was unconstitutional. It was clear that Heikkila could have obtained review of the deportation order in a habeas corpus proceeding once he had been arrested to be deported. ${ }^{15}$ Understandably, he preferred to seek review at an earlier stage, relying on section I0 of the APA. ${ }^{16}$ Section 19(a) of the Immigration Act of $1917,{ }^{17}$ however, expressly declared that decisions of the Attorney General as to deportation would be "final." Reading its previous interpretations of section 19 as holding that a deportation order was reviewable only in a habeas corpus proceeding, ${ }^{18}$ the Supreme Court held that the statutory preclusion exception of section 10 of the $\mathrm{APA}^{19}$ applied and that the Immigration Act precluded review of a deportation order in a suit for a declaratory judgment or an injunction.

The Court examined the legislative history of the APA and found that both the Senate and House Committee Reports on the Act had commented: "Very rarely do statutes withhold judicial review."20 The House Report went on to add: "To preclude judicial review under this bill a statute, if not specific in withholding such review, must upon its face give clear and convincing evidence of an intent to withhold it."21 While the Court found that these statements and the general remedial purposes for adopting the APA "counsel a judicial attitude of hospitality towards the claim that $\S 10$ greatly expanded the availability of judicial review," 22 a review of the history of the Immigration Act since its

13. 345 U.S. 229 (1953).

14. Ch. 1024, tit. 1, $\S 22,64$ Stat. 1006 (1950) (now Immigration and Nationality Act $\S 212(a)(28), 8$ U.S.C. $\S 1182(a)(28)(1964))$.

15. See 345 U.S. at 230, 235; Chin Yow v. United States, 208 U.S. 8 (1908).

16. 5 U.S.C. $\S \S 701-06$ (Supp. 1I, 1967).

17. Ch. 29, § 19, 39 Stat. 889 (now 8 U.S.C. § 1254(a) (1964)).

18. 345 U.S. at 234-35. Professor Davis disagrees with this reading of the cases. 4 K. DAvis, ADMINISTRATIVE LAW THEATISE $\S 28.10$, at 50-51 (1958).

19. 5 U.S.C. $\S 701$ (a)(1) (Supp. 11, 1967).

20. S. Doc. No. 248, 79th Cong., 2d Sess. 212, 275 (1946), quoted in 345 U.S. at 232. (S. Doc. No. 248 reprints the legislative history of the APA, including H.R. Rep. No. 1980, 79th Cong., 2d Sess. (1946).)

21. S. Doc. No. 248 , supra note 20 at 275.

22. 345 U.S. at 232. 
inception ${ }^{23}$ pursuaded the majority that: "Clearer evidence that for present purposes the $1 \mathrm{mmigration}$ Act of 1917 is a statute precluding judicial review would be hard to imagine." 24

The standard adopted in Heikkila, the standard of the House Committee Report, is that to preclude review "a statute . . . must upon its face give clear and convincing evidence of an intent to withhold it."2s Professor Davis is critical of this standard. He states that "our whole tradition of statutory interpretation is that what is implicit is as much a part of a statute as what is explicit, and that the meaning of a statute includes what courts find through the processes of interpretation." ${ }^{26}$ Actually, the Heikkila standard does, not prevent the courts from implying a preclusion of review, although it does require that the implication be based on language in the statute. However, in Shaughnessy v. Pedreiro, ${ }^{27}$ the Supreme Court held that a preclusion in a statute enacted subsequent to the APA must be express.

Pedreiro involved a deportation order under the 1 mmigration and Nationality Act of $1952 .{ }^{28}$ The respondent sought to obtain review of the order through an action for a declaratory judgment and an injunction. In Heikkila the Court had pointed out ${ }^{29}$ that it was only considering the application of the APA to the 1917 Immigration Act and was not determining whether the same result would apply under the new Immigration and Nationality Act.

In sustaining review in an action for a declaratory judgment, the Court in Pedreiro relied on the legislative history of the $1952 \mathrm{Act}$, and also on section 12 of the APA, which states: "No subsequent legislation shall be held to supersede or modify the provisions of this chapter except to the extent that such legislation shall do so expressly." 30 The Court declared: "In the subsequent 1952 Immigration and Nationality Act there is no language which 'expressly' supersedes or modifies the expanded right of review granted by $\S 10$ of the Administrative Procedure Act." ${ }_{31}$

23. Id. at 233-35.

24. Id. at 235. Mr. Justice Frankfurter, dissenting, felt that the liberal provisions of the APA should supersede the narrow review previously established by judicial interpretation of the lmmigration Act. He read the legislative history of the APA as indicating that Congress intended to grant review except where to do so would be to abrogate a statute. Id. at 239-40.

25. S. Doc. No. 248, supra note 20, at 275 (emphasis added).

26. 4 K. Davis, Administrative Law Treatise $\S 28.08$, at 37 (1958).

27. 349 U.S. 48 (1955).

28. 8 U.S.C. $\S \S 1101-503$ (1964).

29. 345 U.S. at 232 n.4.

30. Ch. 324, § 12, 60 Stat. 244 (1946) (now 5 U.S.C. $\S 559$ (Supp. 11, 1967))

31. 349 U.S. at 51 . , 
The new Immigration Act contains the same provision as did the 1917 act declaring that deportation orders of the Attorney General are "final." ${ }^{32}$ But the Court refused to be bound by the interpretation which it had given "final" under the 1917 act and which it had applied in Heikkila. It interpreted "final" in the I952 act "as referring to finality in administrative procedure rather than as cutting off the right of judicial review in whole or in part." ${ }^{33}$ Pedreiro thus established the rule that the courts will not hold that a post-APA statute precludes review at a given stage of the administrative process unless the statute expressly so provides. As will be seen, courts may still imply a preclusion in a statute enacted prior to the APA, but the standard is so strict as to make such implication highly unlikely, except where the court feels, as did the Supreme Court in Heikkila, that it is bound by prior decisions.

\section{B. The Food and Drug Cases}

In three recent cases, Abbott Laboratories v. Gardner, ${ }^{34}$ Toilet Goods Association v. Gardner, ${ }^{35}$ and Gardner v. Toilet Goods Association, ${ }^{36}$ the plaintiffs sought pre-enforcement review of regulations promulgated by the Food and Drug Administration. The Supreme Court had to decide whether the Federal Food, Drug, and Cosmetic Act, ${ }^{37}$ an act antedating the APA, ${ }^{38}$ precluded pre-enforcement review of the challenged regulations. While the Federal Food, Drug, and Cosmetic Act $^{39}$ expressly provides for pre-enforcement review of certain FDA regulations, it does not provide for judicial review of regulations of the sort that were at issue in these three cases. ${ }^{40}$ Nonetheless, the Court refused to infer that Congress had, by its omission, precluded preenforcement review of the regulations in question.

Abbott Laboratories arose from a 1962 amendment ${ }^{41}$ to the Federal Food, Drug, and Cosmetic Act which provided, in effect, that labels and

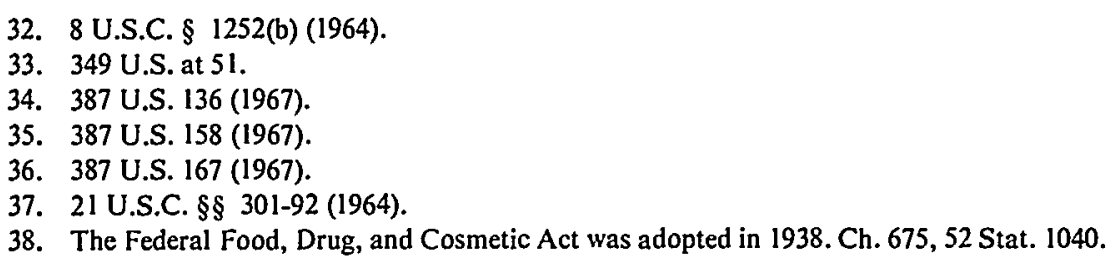
The APA was adopted in 1946. Ch 324, 60 Stat. 237.

39. 21 U.S.C. \$\$ 301-92 (1964).

40. Section 701(f) of the Federal Food, Drug, and Cosmetic Act, 21 U.S.C. \& 371 (f) (1964), provides for review in the courts of appeals of orders issued under $\$ 701(e), 21$ U.S.C. $\$ 371$ (e) (1964). Section 701(e), 21 U.S.C. $\S 371(e)$ (1964), provides a special procedure for the issuance, amendment, and repeal of regulations under specified sections. The regulations at issue in these three cases were promulgated under the general rulemaking authority of $\S 701$ (a), 21 U.S.C. $\S 37 \mathrm{I}(\mathrm{a})$ (1964).

41. Drug Amendments of 1962, Pub. L. No..87-781, 76 Stat. 780. 
advertising of prescription drugs should contain the "established" name of the drug "printed prominently and in type at least half as large as that" used for the proprietary name. ${ }^{42}$ The FDA regulations interpreted the statute to require use of the established name every time the proprietary name was used. ${ }^{43}$ Abbott Laboratories and other drug manufacturers sought a declaratory judgment that the "every time" interpretation was not authorized by the statute and that the regulations were therefore null and void. A federal distriet court found the FDA's every time interpretation to be unauthorized and issued an injunction restraining the enforcement of the regulation. ${ }^{44}$ The Court of Appeals for the Third Circuit vacated the judgment and dissolved the injunction, ${ }^{45}$ holding, inter alia, that Congress had intended the statutory review provisions of the Federal Food, Drug, and Cosmetic Act to be exclusive. The Third Circuit was in turn reversed by the Supreme Court, which remanded the case to the court of appeals to review the district court's decision that the regulation exceeded the FDA's authority. ${ }^{46}$

In the companion cases, the Toilet Goods Association, a trade organization of cosmetic manufacturers, attacked four regulations relating to the Color Additive Amendments of 1960.47 The first regulation ${ }^{48}$ interpreted the statutory definition of "color additive" 49 and the second ${ }^{50}$ defined the term "diluent." that the FDA's definitions considerably expanded the coverage of the statute and would necessitate the costly $y^{32}$ listing and certification of finished products and ingredients which Congress had not intended to include under the act. The dispute over the third regulation ${ }^{53}$ concerned the scope of a statutory exception to the definition of an "adulterated cosmetic" made for "hair dyes" if they are accompanied by a specified

42. Federal Food, Drug and Cosmetic Act $\S \S 502(e)(1)(B),(n)(1), 21$ U.S.C. $\S \S 352(\mathrm{e})(1)(\mathrm{B}),(\mathrm{n})(1)(1964)$.

43. 21 C.F.R. $\S \S 1.104(\mathrm{~g})(1), .105(\mathrm{~b})(1)(1967)$.

44. Abbott Laboratories v. Celebrezze, 228 F. Supp. 855 (D. Del. 1964).

45. Abbott Laboratories v. Celebrezze, 352 F.2d 286 (3d Cir. 1965).

46. 387 U.S. 136 (1967).

47. Pub. L. No. 86-618, 74 Stat. 397.

48. 21 C.F.R. $\$ 8.1(f)(1967)$.

49. Federal Food, Drug, and Cosmetic Act $\S 201(t)(1), 21$ U.S.C. $\S 321(t)(1)(1964)$.

50. 21 C.F.R. \& $8.1(\mathrm{~m})(1967)$.

51. Although not mentioned in the statutory definition of color additive, Federal Food, Drug, and Cosmetic Act $\S 201(t)(1), 21$ U.S.C. $\S 321(t)(1)$ (1964), diluents were included in the regulatory definition, 21 C.F.R. $\S 8.1(1)$ (1967).

52. One manufacturer alleged by affidavit that it would have to spend upward of $\$ 42,000,000$ for laboratory tests and $\$ 7,000,000$ in listing fees in order to comply with the regulations. Gardner v. Toilet Goods Ass'n, 387 U.S. 167, 173 (1967).

53. 21 C.F.R. $\S 8.1(\mathrm{u})(1967)$. 
warning..$^{54}$ Finally, the manufacturers complained that the fourth regulation ${ }^{55}$ sought to expand the FDA's inspection powers. ${ }^{56}$

The Government moved to dismiss the cosmetic manufacturers' complaint on the ground, among others, that the case was inappropriate for declaratory relief. On an interlocutory appeal ${ }^{57}$ the Court of Appeals for the Second Circuit affirmed the denial of the motion as to the first three regulations, but held that the possibility of unlawful injury to the manufacturers from the fourth regulation was too remote to sustain an action for declaratory relief. It therefore instructed the district court to grant the motion to dismiss the fourth count. ${ }^{58}$ Both parties appealed, and in separate opinions ${ }^{59}$ the Supreme Court affirmed the decision of the Second Circuit.

The first question the Court considered in Abbott Laboratories was "whether Congress by the Federal Food, Drug, and Cosmetic Act intended to forbid pre-enforcement review of this sort of regulation ... ." The Court stated:

The question is phrased in terms of "prohibition" rather than "authorization" because a survey of our cases shows that judicial review of a final agency action by an aggrieved person will not be cut off unless there is persuasive reason to believe that such was the purpose of Congress. ${ }^{6 !}$

The Government's argument for preclusion of review in the three FDA cases was that the Federal Food, Drug, and Cosmetic Act included a specific procedure for judicial review of certain FDA regulations. ${ }^{62}$ Since the statute made no provision for the regulations at issue in the three cases, the Government contended that the statute precluded review.

54. Federal Food, Drug, and Cosmetic Act $\S 601$ (a), 21 U.S.C. $\S 361$ (a) (1964).

55. 21 C.F.R. $\$ 8.28$ (1967).

56. The inspection powers of the FDA are set forth in $\S 704$ of the Federal Food, Drug, and Cosmetic Act, 21 U.S.C. $\$ 374$ (1964). By the Drug Amendments of 1962, Congress extended the power of inspection where prescription drugs are involved to include the inspection of "records, files, papers, processes, controls, and facilities." Pub. L. No. 87-781, tit. 11, $\$ 201$ (a), 76 Stat. 792. The regulation extends this power to inspection involving the manufacture of color additives. 21 C.F.R. 8.28 (1967).

57. Under 28 U.S.C. $§ 1292(b)$ (1964). Toilet Goods Ass'n v. Gardner, 360 F.2d 677, 679-80 (2d Cir. 1966).

58. Toilet Goods Ass'n v. Gardner, 360 F.2d 677, 688 (2d Cir. 1966).

59. Toilet Goods Ass'n v. Gardner, 387 U.S. 158 (1967), Gardner v. Toilet Goods Ass'n, 387 U.S. 167 (1967). At the subsequent trial, the court awarded the Toilet Goods Association judgment on all three remaining counts. Toilet Goods Ass'n v. Gardner, 278 F. Supp. 786 (S.D.N.Y. 1968).

60. Abbott Laboratories v. Gardner, 387 U.S. 136, 139 (1967).

61. Id. at 140 .

62. See note 40 supra. 
Unpersuaded by this line of argument, the Abbott Court quoted with approval ${ }^{63}$ Professor Jaffe's statement: "The mere fact that some acts are made reviewable should not suffice to support an implication of exclusion as to others. The right to review is too important to be excluded on such slender and indeterminate evidence of legislative intent." 64 There is nothing startling about this proposition. In fact, even before the enactment of the APA, the Court had found in Stark $v$. Wickard $^{65}$ that the inclusion in the Agricultural Marketing Agreement Act of $1937^{66}$ of specific provisions for review showed "the intent to submit many questions arising under its administration to judicial review." 67 The Stark Court, thus, used the express provisions for review to support review under the general jurisdiction of the district court in a situation where the express provisions did not apply.

The Abbott Laboratories majority was of the opinion that "a study of the legislative history [of the Federal Food, Drug, and Cosmetic Act] shows rather conclusively that the specific review provisions were designed to give an additional remedy and not to cut down more traditional channels of review." 68 The dissenters took strong issue with this conclusion. After examining the legislative history of the Federal Food, Drug, and Cosmetic Act and distinguishing the cases relied on by the majority, ${ }^{69} \mathrm{Mr}$. Justice Fortas concluded:

1t was Congress' judgment, after much controversy, that the special nature of the Act and its administration required this protection against delay and disruption. We should not arrogate to ourselves the powcr to override this judgment. Not a single case cited by the majority in which

63. 387 U.S. 136, 141 (1965).

64. L. JafFe, Judicial Control of Administrative Action 357 (1965).

65. 321 U.S. 288 (1944).

66. Ch. 296, 50 Stat. 246 (codified in scattered sections of 7 U.S.C.). Sections $1 \& 2$ of ch. 296 affirmed and reenacted specified sections of the Agricultural Adjustment Act of 1933.

67. 321 U.S. 288, 308 (1944).

68. 387 U.S. 136, 142 (1967). The majority relied partly on the saving clause in 21 U.S.C. $\S 371(f)(6)$ (1964) which declares: "The remedies provided for in this subsection shall be in addition to and not in substitution for any other remedies provided by law." Abbott Laboratories v. Gardner, 387 U.S. 136, 144-45 (1967). Fortas found that this subparagraph only applied to the regulations speeified in 21 U.S.C. $\$ 371$ (e) (1964). Gardiner v. Toilet Goods Ass'n, 387 U.S. 167, 180 (1967) (dissenting opinion). The majority pointed out that both the majority and minority reports on the review provisions, H.R. Rep. No. 2139, 75th Cong., 3d Sess. (1938), acknowledged the availability of traditional methods of judicial review, but differed as to the need for additional procedures. The regulations reviewable under 21 U.S.C. $371(f)$ (1964) involvc technical factual determinations, and the special review provisions were intended to provide a broader scope of review than the traditional injunctive suit, which only permits reversal if the findings are "arbitrary and capricious." Furthermore, the procedures provided broader venue than was available at the time. Abbott Laboratories v. Gardner, 387 U.S. 136, 142-44 (1967).

69. Gardner v. Toilet Goods Ass'n, 387 U.S. 167, 178-85 (1967) (dissenting opinion). 
agency action was held reviewable arose against this kind of background of legislative hostility to threshold review in the district courts. ${ }^{70}$

The Abbott Laboratories standard is that "only upon a showing of 'clear and convincing evidence' of a contrary legislative intent should the courts restrict access to judicial review."71 This test is difficult to meet. The mere fact that the legislative history is susceptible to conflicting readings-compare the majority and minority readings of the legislative history of the Federal Food, Drug, and Cosmetic Act-should be sufficient to prevent the Court fro $\mathrm{n}$ finding "clear and convincing evidence" that Congress intended to preclude pre-enforcement review. Unlike the standard in Heikkila v. Barber, ${ }^{72}$ however, the Abbott Laboratories standard does not require that the "clear and convincing evidence" necessary to imply a preclusion be apparent on the face of the statute.

Still, Justice Fortas felt that the Abbott Court failed to pay sufficient attention to congressional intent:

The Court seems to announce a doctrine, which is new and startling in administrative law, that the courts, in determining whether to exercise jurisdiction by injunction, will not look to see whether Congress intended that the parties should resort to another avenue of review, but will be governed by whether Congress has "prohibited" injunctive relief. ${ }^{73}$

In support of his view, Justice Fortas cites Switchmen's Union v. National Mediation Board, ${ }^{74}$ which was decided in 1943 , prior to the enactment of the APA. There the Court held that the statute precluded review of an order of the Board determining the basis for a representation election. The Court relied on the fact that, as in $A b b o t t$ Laboratories, the statute specified a procedure for review of certain other actions of the Board. ${ }^{75}$

It is clear, however, that Congress took account of Switchmen's Union in drafting section 10 . As originally proposed by the sponsors, the APA exclusion would have applied only if a statute expressly precluded review. ${ }^{76}$ At the suggestion of the Attorney General, ${ }^{77}$ the bill was

70. Id. at 187 .

71. 387 U.S. 136,141 (1967).

72. 345 U.S. 229, 232 (1953). Actually, the Heikkila Court itself paid little attention to the limitation. The evidence on the face of the statute there in question was merely that decisions of the Attorney General were declared to be "final." See id. at 232-35.

73. Gardner v. Toilet Goods Ass'n, 387 U.S. 167, 183-84 (1967) (dissenting opinion).

74. 320 U.S. 297 (1943), cited in 387 U.S. at 177, 185.

75. See 320 U.S. at 305-06.

76. H.R. 1203, 79th Cong., lst Sess. $§ 10$ (1945).

77. Appendix to Attorney General's Statement Regarding Revised Committee Print of 
modified to permit implied preclusions such as that in Switchmen's Union. By eliminating the word "expressly" from section 10, Congress indicated a desire not to overrule prior judicial decisions which had implied preclusions of review; however, this should not be allowed to obscure the more basic fact that the APA evinces a congressional attitude favoring review. ${ }^{78}$ The Act and its legislative history clearly demand that the courts be reluctant to restrict access to judicial review when they are not bound by pre-APA interpretations implying a preclusion. The strictness of the Abbott Laboratories standard is therefore eminently appropriate.

\section{The Argument for a Strict Standard}

The requirement of Abbott Laboratories $v$. Gardner that congressional intent to preclude review must be "clear and convincing" before review will be cut off comes close to requiring that Congress explicitly state that review is not permitted except as provided for. There are good reasons why this should be the rule.

As to legislation enacted since 1946, there is little difficulty in insisting on the requirement of section 12 of the Administrative Procedure Act $^{79}$ that subsequent legislation shall only supersede or modify the provisions of the APA to the extent that it does so expressly. Where the statute in question is one which was enacted prior to the adoption of the APA, it would still seem unreasonable to condition the availability of adequate judicial review ${ }^{80}$ - even if it be only the availability of review at a particular stage of the administrative process-on something as susceptible to varying interpretations as is congressional intent.

The timing of review is an important matter. Postponement of review may permit an agency to stretch its authority and may effectively deny adequate review of the agency's actions. For example, if there is no

October 5, 1945, reprinted in S. Doc. No. 248, 79th Cong., 2d Sess. 229-30 (1946).

78. See Wong Yang Sung v. McGrath, 339 U.S. 33, 36-41 (1950). The Court examines the forces which led to the adoption of the APA and concludes that despite the compromises the Act was intended to remedy past problems. In Heikkila v. Barber the Court declared that the legislative history and "the broadly remedial purposes of the Act counsel a judicial attitude of hospitality towards the claim that $\S 10$ greatly expanded the availability of judicial review." 345 U.S. 229, 232 (1953). This view is criticized by Professor Davis, $4 \mathrm{~K}$. Davis, Administrative Law Treatise $\S 28.08$, at 35-42 (1958). For a reply to Professor Davis' interpretation see Berger, Administrative Arbitrariness and Judicial Review, 65 CoLuM. L. REv. 55, 65-69 (1965).

79. 5 U.S.C. $\$ 559$ (Supp. II, 1967).

80. Judicial review under $\S 10$ of the APA is available only if the plaintiff has "no other adequate remedy in a court." Section 10(c) of the APA, 5 U.S.C. $\S 704$ (Supp. 11, 1967). 
means by which a party can obtain review of an administrative order without risking criminal prosecution, he may prefer to comply and lose his chance for judicial review, rather than risk a finding that the agency was acting within its authority and, therefore, that he has committed a crime by disobeying its order.

Congress may nevertheless wish to limit review to criminal actions in order to speed compliance with its policy. Whether it can constitutionally so restrict review is beyond the scope of this Comment; ${ }^{81}$ but, at a minimum, it should be required to give explicit expression to any such limitation on reivew. If Congress has not expressly limited review to enforcement proceedings, but it seems clear that it was concerned about the danger of harm to the public resulting from delay in the implementation of an agency's decisions, this is a matter which the courts should take into consideration in deciding whether to grant or withhold temporary relief during trial..$^{82}$

It is worth noting, however, that the danger of such harm diminishes as the agency ages. Once the agency has dealt with the core problems that led Congress to establish it, it tends to move into spheres where regulation is of more marginal importance. Thus, it is doubtful that immediate implementation of the regulation involved in the $\mathrm{Abbott}$ Laboratories case was of vital interest to the protection of the public. The manufacturers had already taken steps to see that the labels and advertising of their prescription drugs contained the "established" name of the drug in a prominent place as the statute ${ }^{83}$ required. The Commissioner, however, by regulation ${ }^{84}$ interpreted the statute to require use of the established name every time the proprietary name was used. Whether one agrees with the Commissioner's interpretation or not, one can doubt that this is a situation in which speedy implementation of the agency action is necessary. Congress is not faced with individual cases; the courts are.

Where, as in Abbott Laboratories, Congress has provided a special statutory form of review for certain actions and not for others, it is not a foregone conclusion that it has decided to restrict review of other agency actions in order to speed implementation of measures to protect the public. Indeed, Congress may have determined that while the ordinary

81. For an argument that at least some review is constitutionally required see Berger, Administrative Arbitrariness and Judicial Review, 65 Colum. L. Rev. 55 (1965). But see $4 \mathrm{~K}$. Davis, Administrative Lalw TREatise $§$ 28.18-19 (1958).

82. See text accompanying notes $145-48$ infra.

83. Fedcral Food, Drug, and Cosmetic Act $\S \S 502(e)(1)(B),(n)(1), 21$ U.S.C. $\S \S 352(\mathrm{e})(1)(\mathrm{B}),(\mathrm{n})(1)(1964)$.

84. 21 C.F.R. $\S 1.104(\mathrm{~g})(1), .105(\mathrm{~b})(\mathrm{l})(1967)$. 
course of review will suffice for the other measures, speedier review through the courts of appeal is desirable for the designated agency actions. In the alternative, Congress may have wished to provide a broader scope of review for the designated actions than would be available in an action in the district court. ${ }^{85}$

Note that section 10 makes the APA provisions for judicial review inapplicable "to the extent that-(1) statutes preclude judicial review; or (2) agency action is committed to agency discretion by law." ${ }^{86}$ This suggests that Congress intended to permit the courts to find a preclusion only when it is clear from the statute itself that Congress intended one, but to allow the courts greater leeway in determining what matters are committed to agency discretion. Where the question is one of the allocation of powers between the agency and the judiciary, it makes sense to have the courts investigate fully the intent of Congress. The courts are free to do so in determining whether an action is committed to agency discretion. But where preclusion is directed towards the question of the timeliness of review-a matter particularly suited for the individualized judgment of the courts--the courts should not imply a preclusion in the absence of clear and convincing evidence that such was Congress' intent.

II

\section{RIPENESS AND THE \\ ADMINISTRATIVE PROCEDURE ACT}

A dispute with an administrative agency is usually a continuing matter and may go through many stages of the administrative process. For example, after an agency has promulgated a regulation - already an advanced stage of the administrative process - the dispute may continue through the stages of a warning of violation, the taking of administrative sanctions, and, eventually, the attempt to impose civil or criminal sanctions. At each stage there may be an opportunity for a hearing, and at some stages there may even be a clear statutory right to judicial consideration of the dispute. Presumably the issues, the points of difference between the agency and the parties affected by its action, will become clearer at each succeeding stage. The courts therefore prefer to wait as long as possible before considering the issues; even if the statute in question does not preclude review during the early stages of a dispute, they will not decide a case until it is "ripe."

The reasons for the ripeness requirement were summarized in

85. See Abbott Laboratories v. Gardner, 387 U.S. 136, $142-44$ (1967).

86. 5 U.S.C. $\S 701$ (a) (Supp. 11, 1967) (emphasis added). 
Abbott Laboratories v. Gardner as follows:

[The] basic rationale is to prevent the courts, through avoidance of premature adjudication, from entangling themselves in abstract disagreements over administrative policies, and also to protect the agencies from judicial interference until an administrative decision has been formalized and its effects felt in a concrete way by the challenging parties. ${ }^{87}$

Whether a dispute is ripe will depend on "the fitness of the issues for judicial decision and the hardship to the parties of withholding court consideration." 88

\section{A. Appropriateness of the Issues}

The appropriateness of the issues for judicial consideration is not solely a question of ripeness; it may also be a question of review vel non. For example, if the agency action challenged is one committed totally to agency discretion, the complaint will present no issues which are appropriate for judicial consideration at any time. Similarly, if a statute makes an agency's findings of "fact" conclusive, a complaint that an agency regulation is void because it is based on erroneous findings of fact will not present any issue that the judiciary is competent to consider. ${ }^{89}$ Here, however, it is assumed that the courts are competent to decide the issues raised, and the question is whether the issues are sufficiently clear, and the agency's position sufficiently fixed, so that judicial consideration is appropriate.

\section{l. Final Agency Action}

Section 10(c) of the Administrative Procedure Act provides for judicial review of "[a]gency action made reviewable by statute and final agency action for which there is no other adequate remedy in a court." ${ }^{\prime 90}$ The APA definition of "agency action" administrative acts which are not sufficiently formal to come within the definition, ${ }^{92}$ but the term "final" is not defined in the APA.

87. 387 U.S. $136,148-49$ (1967).

88. Id. at 149. The Supreme Court makes a similar statement in Toilet Goods Ass'n v. Gardner, 387 U.S. 158, 162 (1967).

89. On the law-fact distinction see L. JafFe, Judicial CONTROL of Administrative Action chs. 14,15 (1965).

90. 5 U.S.C. $\$ 704$ (Supp. 11, 1967).

91. Section 2(g), 5 U.S.C. § 55l(13) (Supp. 11, 1967).

92. See Hearst Radio, Inc. v. FCC, 167 F.2d 225 (D.C. Cir. 1948) where the court examined the APA definitions and held that it could not review the publication of unfavorable remarks about the plaintiff in an FCC report. 
In Abbott Laboratories $v$. Gardner, ${ }^{93}$ the Supreme Court indicated that it would rely on its decisions under the Urgent Deficiencies Act ${ }^{94}$ in interpreting the meaning of "final" in the APA. This reliance is somewhat confusing. The Urgent Deficiencies Act gave the district courts jurisdiction to review "orders" of the ICC. The review provisions were incorporated into the statutes governing other agencies, notably the FCC. 95 The Urgent Deficiencies Act, however, did not speak of "final" orders. The Court read the concept of finality into the Act: its determination that an order was "final" was a decision that it was ripe for review. ${ }^{96}$ By contrast, in Toilet Goods Association v. Gardner the Court held that the disputed regulation was a final agency action within the meaning of the A.PA, but that it was not ripe for review. ${ }^{97}$ Thus, "final" as used in section 10(c) means something less than "final" as used in the Urgent Deficiencies Act cases. Precisely how much less remains uncertain; however, two lower court decisions shed some light on the matter.

The second sentence of section 10(c) declares that: "A preliminary, procedural, or intermediate agency action or ruling not directly reviewable is subject to review on the review of the final agency action." 98 The First Circuit, in Eastern Utilities Associates v. SEC, ${ }^{99}$ apparently relied on this language in holding that the APA did not change the prior rule that "administrative orders of a merely preliminary or procedural character are not directly and immediately reviewable in the circuit court of appeals." 100 There the petitioners sought to substitute Boston for Philadelphia as the place for an SEC hearing, relying on the requirement in section 5(a) of the $\mathrm{APA}^{101}$ that "[i]n fixing the time and place for hearings, due regard shall be had for the convenience and necessity of the parties or their representatives." In Sperry and Hutchinson Company v. FTC, ${ }^{102}$ however, a district court indicated that review of preliminary

93. 387 U.S. 136, 149-50 (1967).

94. Ch. 32, 38 Stat. 219 (1913) (now 28 U.S.C. §§ 2321-25 (1964)).

95. Section 402(a) of the Communications Act of 1934, ch. 652, tit. IV, 48 Stat. 1093 made the provisions of the Urgent Deficiencies Act applicable to the FCC. A new review provision was adopted in 1952, 47 U.S.C. $\$ 402$ (a) (1964).

96. See Rochester Tel. Corp. v. United States, 307 U.S. 125, 139 (1939). The Court there speaks of only two limitations on judicial review of ICC orders-the primary jurisdiction doctrine, which relates to the law-fact distinction, and "the doctrine of administrative finality."

97. 387 U.S. $158,162-63$.

98. 5 U.S.C. $\$ 704$ (Supp. 11, 1967).

99. 162 F.2d 385 (1st Cir. 1947).

100. Id. at 386 .

101. 5 U.S.C. § 554(b) (Supp. II, 1967).

102. 256 F. Supp. 136 (S.D.N.Y. 1966). 
orders is permissible if the plaintiff can show that he is threatened with "irreparable injury." 103 Since the plaintiff must make a greater showing of harm in order to obtain the nonstatutory review, ${ }^{104}$ Sperry is not inconsistent with Eastern Utilities.

Sperry indicates that the term "final" in section $10(\mathrm{c})$ means "effective." This is supported by the House report on the Administrative Procedure Act which states: "Final' action includes any effective or operative agency action for which there is no other adequate remedy in any court."'os The effectiveness of an agency action will depend on the possibility of a change in the agency's position before the plaintiff is substantially affected by the action. The immediacy of the impact of the agency's action will be discussed later. ${ }^{106}$ For the moment it suffices to say that the agency must have taken some sort of fixed position before the courts will grant review.

\section{Clarity of the Issues}

The three food and drug cases furnish a good study of the requirement that the issues be clear before the courts will review an administrative action. The clearest issues were those raised in Abbott Laboratories $v$. Gardner, which involved an interpretive regulation. There was no contention that it was necessary "for the efficient enforcement of [the Federal Food, Drug, and Cosmetic Act]"107 that drug manufacturers use the "established name" of a drug every time ${ }^{108}$ they used the proprietary name. The agency merely asserted that this was required by the statute. ${ }^{109}$ In reality, therefore, if the agency was correct in its interpretation, the promulgation of the regulation amounted to nothing

103. See id. at 140-41. In the following sentence the court indicated that the requirement of irreparable injury would be met by "a showing of a "substantiality of present or immediate harm," citing Toilet Goods Ass'n v. Gardner, 360 F.2d 677, 685 (2d Cir. 1966).

104. A statute may give standing to one who is "affected adversely" by agency action, but " $[t] 0$ require a court to intervene in the absence of a statute . . . something more than adverse personal interest is needed." Joint Anti-Fascist Refugee Comm. v. McGrath, 341 U.S. 123, 151 (1951) (concurring opinion of Frankfurter, J.). This rule is embodied in $\S 10$ (a) of the APA, 5 U.S.C. $\$ 702$ (Supp. 11, 1967), Kansas City Power \& Light Co. v. McKay, 225 F.2d 924 (D.C. Cir.), cert. denied, 350 U.S. 884 (1955).

105. S. Doc. No. 248 , supra note 20 , at 277.

106. See text accompanying notes $118-25$ infra.

107. Federal Food, Drug, and Cosmetic Act $\S 701$ (a), 21 U.S.C. $\S 371$ (a) (1964).

108. 21 C.F.R. $\$ \S 1.104(\mathrm{~g})(\mathrm{l}), .105(\mathrm{~b})(\mathrm{I})$ (1967).

109. The Court in Abbott Laboratories $v$. Gardner agreed that the regulation might vary with its application, but said "the suggestion overlooks the fact that both sides have approached this case as one purely of congressional intent, and that the Government made no effort to justify the regulation in factual terms." 387 U.S. 136, 149 (1967). 
more than a warning that the agency intended to enforce the statute. The issues would not have differed one jot had the agency instead instituted a liabel proceeding or a suit for an injunction. There is no reason why the court should refuse to consider the issue merely because it arose in the way that it did. Indeed, in California the problem could clearly have been raised in a suit for a declaratory judgment. ${ }^{110}$

A legislative regulation is less likely to present clearcut issuesissues appropriate for immediate judicial consideration-than is an interpretive regulation. This is so because whether the regulation is one which is "necessary and proper" will often depend on how the agency applies and interprets its own regulation. Thus, in Toilet Goods Association $v$. Gardner, although the plaintiffs attempted to frame a clear legal issue-that since the agency had sought an authorization from Congress to make inspections of the type provided for in the regulation and Congress had not given it, the agency had exceeded its authority in making such a regulation-the Supreme Court pointed out that the agency did have the power to make regulations "for the efficient enforcement" of the Food, Drug, and Cosmetic Act." As the Court declared:

Whether the regulation is justified thus depends not only, as petitioners appear to suggest, on whether Congress refused to include a specific section of the Act authorizing such inspections, although this factor is to be sure a highly relevant one, but also on whether the statutory scheme as a whole justified promulgation of the regulation. . . . This will depend not merely on an inquiry into statutory purpose, but concurrently on an understanding of what types of enforcement problems are encountered by the FDA, the need for various sorts of supervision in order to effectuate the goals of the Act, and the safeguards devised to protect legitimate trade secrets. . . .112

Even an "interpretive" regulation might not present clear legal issues, however. For example, in Gardner v. Toilet Goods Association one of the regulations in issue ${ }^{113}$ interpreted the statute to require the

110. CAL. Gov'T CODE $\& 11440$ (West 1966) states; "Any interested person may obtain a judicial declaration as to the validity of any regulation by bringing an action for declaratory relief in the superior court in accordance with the provisions of the Code of Civil Procedure. . . "See Chas. L. Harney, Inc. v. Contractors' State License Bd., 39 Cal. 2d 561, 247 P.2d 913 (1952).

In California, the plaintiffs might have been able to obtain review of a similar state statute even in the absence of any action by the agency since the California supreme court has held that "[t]he interpretation of ordinances and statutes are proper matters for declaratory relief." Walker v. County of Los Angeles, 55 Cal. 2d 626, 637, 361 P.2d 247, 253, 12 Cal. Rptr. 671, 677 (1961).

111. Federal Food, Drug, and Cosmetic Act $\S 701$ (a), 21 U.S.C. $\$ 371$ (a) (1964).

112. 387 U.S. $158,163-64$ (1967).

113. 21 C.F.R. $\$ 8.1($ (1967). 
listing of "diluents." The statute included within the definition of a "color additive" any "dye, pigment, or other substance" which "when added or applied to a food, drug, or cosmetic, or to the human body or any part thereof, is capable (alone or through reaction with another substance) of imparting color thereto." 114 Thus, whether a particular diluent fell within the scope of the statute might involve a factual question. However, the Supreme Court noted that this issue was not before it, inasmuch as the case arose on a motion to dismiss ${ }^{115}$ and there was nothing to show that "consideration of the underlying legal issues would necessarily be facilitated" by postponing review. ${ }^{16}$

These examples of interpretive and legislative regulations show that labels are of limited utility in determining when an administrative action will be ripe for review. What matters is whether the issues raised are as clear at the time review is sought as they will be later on; and, if not, whether the benefits that delay would yield in clarifying the issues are outweighed by the harm that the plaintiff would or might incur as a result of the delay.

\section{B. Hardship to the Parties}

Where a plaintiff is not seeking review under a specific statutory provision, the APA requires that he have "no other adequate remedy in a court." 117 Whether later access to judicial review is an adequate remedy will depend on the immediacy, certainty, nature, and magnitude of the harm with which the plaintiff is threatened.

\section{Immediacy and Certainty of the Threatened Injury}

The immediacy and certainty of the harm ${ }^{118}$ are among the elements courts will weigh in deciding whether a case is ripe for judicial review. In Toilet Goods Association v. Gardner, the Supreme Court held that the dispute was not ripe for review in part because there was no imminence or certainty of harm. The regulation at issue $e^{119}$ authorized the Commissioner of Food and Drugs to suspend certification of color

114. 21 U.S.C. $\$ 321(t)(1)$ (1964) (emphasis added).

115. The Court suggested in a footnote that if technical questions were raised on remand, the district court would have to reconsider the ripeness problem. Gardner v. Toilet Goods Ass'n, 387 U.S. 167, 171 n.I (1967).

116. Id. at 171 .

117. Section 10(c), 5 U.S.C. $\$ 704$ (Supp. 11, 1967).

118. The harm may occur long before the effective date of a regulation or statute. Thus, in Pierce v. Society of Sisters, 268 U.S. 510 (1925), a statute was invalidated fifteen months before it would have become effective. The statute would have required all parents to send their children to public schools, and plaintiffs alleged that as a result parents were already withdrawing their children from their schools.

119. 21 C.F.R. \& 8.28(a)(4) (1967). 
additives if a manufacturer refused to permit duly authorized employees of the Food and Drug Administration access to all manufacturing facilities, processes, and formulae involved in the manufacture of color additives and intermediates from which color additives were derived. There was no certainty that the Commissioner would ever find it necessary to make such inspections or, if he did, that he would suspend certification upon a refusal to permit it. More important, the manufacturers were under no constraint to take any action until the agency sought to make an inspection. The petitioners alleged that if the Commissioner exercised his asserted authority, they would be forced either to permit the inspections and risk the loss of trade secrets-presumably through indiscretion of the inspectors-or to refuse to permit inspection and risk the loss of certification. If they chose the latter alternative and certification were denied, the denial would be subject to challenge at an administrative hearing, ${ }^{120}$ which in turn would be reviewable by a court. ${ }^{121}$ If denial of certification proved a hardship, the Court suggested, the manufacturers might avoid or minimize their damage by compliance, with a reservation pending litigation. ${ }^{122}$

The Court practically ignored one traditional element of certainty-the threat of enforcement-in the three food and drug cases, ${ }^{123}$ although it recently used that element to avoid passing on a challenge to the constitutionality of a state statute. ${ }^{124}$ This may indicate acceptance of Professor Jaffe's proposal that "constitutional law cases be put more or less to the side (though they need not be completely ignored) in constructing ripeness requirements in administrative law." 25 At least where a regulation is recent, one may presume that the agency

120. 21 C.F.R. $\S \S 8.28(b), 130.14-.26$ (1967).

121. There was some doubt as to whether review would be by a court of appeals or by a district.court. See Toilet Goods Ass'n v. Gardner, 387 U.S. 158, 165 n.3 (1967).

122. Id. at 165 n.2. If the remedies suggested by the Court proved inadequate, the manufacturer might succeed in obtaining injunctive relief at this stage.

123. The Government raised the question, pointing out that the Food and Drug Administration would have to convince the Attorney General to prosecute any violations. The Court answered: "In the context of this case, we do not find this argument persuasive. These regulations are not meant to advise the Attorney General, but purport to be directly authorized by the statute. Thus, if within the Commissioner's authority, they have the status of law and violations of them carry heavy criminal and civil sanctions. Also, there is no representation that the Attorney General and the Commissioner disagree in this area; the Justice Department is defending this very suit." Abbott Laboratories v. Gardner, 387 U.S. 136, 151-52 (1967).

124. Poe v. Ullman, 367 U.S. 497 (1961) The development of the requirement that there be a threat of enforcement before the courts can pass on the constitutionality of a statute is traced in Comment, Threat of Enforcement-Prerequisite of a Justiciable Controversy, 62 CoLUM. L. Rev. 106 (1962).

125. L. Jaffe, Judicial Control of Administrative Action 397-98 (1965) (footnote omitted). 
will try to enforce it and that the Attorney General will carry out the prosecution for the agency.

\section{Nature of the Threatened Injury}

Professor Jaffe has stated: "Administrative law borrows from equity the notion that it may be unfair to require a person to incur the risk of punishment or forfeiture in order to learn whether or not a line of conduct is valid." 126 Indeed, Justice Fortas, dissenting to the grants of judicial review in Abbott Laboratories and Gardner, conceded that: "Where personal status or liberties are involved, the courts may well insist upon a considerable ease of challenging administrative orders or regulations." ${ }^{27}$

Often, however, the risk of serious criminal punishment may be very slight or very serious depending on the action the agency is likely to take to enforce its determination. Thus, the seriousness of the penalties risked in Abbott Laboratories was very much dependent on whether the agency would choose to enforce its regulations by seeking an injunction or whether it would institute libels or criminal proceedings. ${ }^{128}$ In such cases the Court should consider whether the agency is trying to avoid judicial review by threatening such stringent enforcement of its regulations that the regulated parties will prefer to comply with the regulations even though by complying they will lose their chance to challenge the agency's action. ${ }^{129}$

Agency action may produce harm of a sort that only immediate judicial review can alleviate. For example, in Columbia Broadcasting System $v$. United States ${ }^{130}$ the FCC had promulgated regulations which provided that licenses would not be granted to stations having certain forms of contracts, agreements, or understandings with a network organization. ${ }^{131}$ Although the FCC did not have authority to regulate contractual relations between stations and networks, its regulations had the effect of declaring that such contracts and agreements were not in the public interest and warning stations thus violating the public interest

126. Id. at 403 .

127. Gardner v. Toilet Goods Ass'n, 387 U.S. 167, 187 (1967) (citing Rusk v. Cort, 369 U.S. 367 (1962)).

128. Drugs with non-complying labels and advertising would be misbranded, Federal Food, Drug, and Cosmetic Act $\S \S 502(\mathrm{e})(\mathrm{l})(\mathrm{B}),(\mathrm{n})(1), 21$ U.S.C. $\S \S 352(\mathrm{e})(1)(\mathrm{B}),(\mathrm{n})(1)$ (1964), and their introduction into interstate commerce would be a prohibited act, $\S 301$ of the Act, 21 U.S.C. $\$ 331$ (1964), subject to enforcement by injunction, criminal penalties, and seizures, $\S \S 302-04$ of the Act, 21 U.S.C. $\$ \S 332-34$ (1964).

129. See L. Jaffe, Judicial Control of Administrative Action 413-15 (1965).

130. 316 U.S. 407 (1942).

131. Chain Broadcasting Regulations, 47 C.F.R. $\S \S 3.101-.109$ (Supp. 1941), reprinted in 316 U.S. 407 at $425-28$. 
that they would be unable to obtain FCC approval when it came time to renew their licenses. ${ }^{132}$ The day after CBS filed suit, ${ }^{133}$ the FCC declared that it was willing to test the regulations by granting an immediate hearing to a station which had one of the disfavored contracts. If after the hearing the agency decided to enforce its regulations, and if the regulations were upheld on appeal, the agency declared that it would nonetheless renew the license of the station if it had otherwise met the requirements for renewal and would agree in the future to respect the regulations. ${ }^{134}$ CBS's problem, however, was that without contracts such as those forbidden by the regulations the network would collapse and that as a result of the Commission's order its affiliates were cancelling and repudiating their contracts and had continued to do so even after the issuance of the minute authorizing a test case. ${ }^{35}$ Because the FCC had chosen to act by issuing regulations, it had created a situation in which immediate judicial review was necessary to protect the network from the alleged harm. The Court, therefore, held that CBS could sue to enjoin the enforcement of the regulation.

By contrast, while the cost of compliance in Abbott Laboratories $v$. Gardner ${ }^{136}$ and in Gardner v. Toilet Goods Association ${ }^{137}$ was alleged to be substantial, ${ }^{138}$ the cost of non-compliance would likely be slight. The agency probably would have sought to enforce its regulations by injunctions, ${ }^{139}$ or by an isolated test seizure. This might have resulted in some adverse publicity, ${ }^{140}$ but the gravity of this result is susceptible to

132. See Columbia Broadcasting Sys. v. United States, 316 U.S. 407, 430-32 (1942) (dissenting opinion).

133. The complaint was filed Oct. 30, 1941, 316 U.S. $407,413$.

134. FCC Minute of Oct. 31, 1941, reprinted in 316 U.S. 407 at 428.

135. 316 U.S. $407,414$.

136. 387 U.S. 136 (1967).

137. 387 U.S. 167 (1967).

138. See note 52 supra.

139. "[T]he Solicitor General has represented that if court enforcement becomes necessary, 'the Department of Justice will proceed only civilly for an injunction . . . or by condemnation.' We cannot accept this argument as a sufficient answer to petitioners' petition. This action at its inception was properly brought and this subsequent representation of the Department of Justice should not suffice to defeat it." Abbott Laboratories v. Gardner, 387 U.S. 136, 154 (1967).

Justice Fortas deelared: "Actually, if the Court refused to permit this shotgun assault, experience and reasonably sophisticated commonsense show that there would be orderly compliance without the disaster so dramatically predicted by the industry, reasonable adjustments by the agency in real hardship cases, and where extreme intransigence irivolving substantial violations occurred, enforcement actions in which legality of the regulation would be tested in specific, concrete situations." Gardner v. Toilet Goods Ass'n, 387 U.S. 167, 199 (1967) (dissenting opinion).

140. The Court deelared in Abbott Laboratories v. Gardner: "lt is relevant at this juncture to recognize that petitioners deal in a sensitive industry, in which public confidence in their drug products is espeeially important. To require them to challenge these regulations only as a defense to an action brought by the Government might harm them severely and unnecessarily." 387 U.S. 136, 153 (1967). 
doubt. In such a case, the question really becomes one of the appropriateness of the issues for judicial resolution.

\section{Advantages of Relying on the Ripeness Doctrine to Limit Review}

In his dissent to Abbott Laboratories v. Gardner and Gardner v. Toilet Goods Association, ${ }^{141}$ Justice Fortas declared: "The Court, by today's decisions . . . has opened Pandora's box. Federal injunctions will now threaten programs of vast importance to the public welfare. The Court's holding here strikes at programs for the public health." ${ }_{142} \mathrm{He}$ found it "little more than delusion" 143 to believe, as did the majority, that "a court would refuse to postpone the effective date of an agency action if the Government could show, as it madeno effort to do here, that delay would be detrimental to the public health or safety." ${ }_{144}$ His solution to the problem of how to balance the public need for protection against the private interests of the plaintiffs was simply to declare that Congress had spared the Court the necessity of performing such an act and had, without saying so, precluded review of agency actions except in enforcement proceedings. The more flexible solution of the majority is preferable.

While it is likely that once it has been established that a given agency's regulations are subject to pre-enforcement review, attempts will be made to interfere with the rapid implementation of the agency's regulations by court action, the institution of a suit for review does not in itself stay the effectiveness of a regulation. Such a stay may be obtained under the provisions for judicial review of the APA, ${ }^{145}$ but apparently none was sought in Abbott Laboratories. ${ }^{146}$ And though an agency may grant a stay if it "finds that justice so requires," postpone the effective date "to the extent necessary to prevent irreparable injury." 148 Where the party seeks injunctive relief, a showing

141. The dissent to both cases appears after Gardner v. Toilet Goods Ass'n, 387 U.S. 167, 174 (1967).

142. Id. at 176.

143. Id.

144. Abbott Laboratories v. Gardner, 387 U.S. 136, 156 (1967).

145. 5 U.S.C. $\$ 705$ (Supp. 11, 1967).

146. 387 U.S. $136,155-56$ (1967). One reason why the agency might not have attempted to enforce the regulations despite the lack of a stay was that the trial court had decided for the plaintiffs on the merits. Abbott Laboratories v. Celebrezze, 228 F. Supp. 855 (Del. 1964). In Gardner v. Toilet Goods Ass'n and Toilet Goods Ass'n v. Gardner interlocutory appeals were taken under 28 U.S.C. $\$ 1293$ (b) (1964) after the trial court had denied plaintiffs' motion for summary judgment and defendant's motion to dismiss. See 360 F.2d 677 (2d Cir. 1966).

147. § 10(d), 5 U.S.C. § 705 (Supp. 11, 1967).

148. Id. 
of reasonable certainty of success ${ }^{149}$ or the likelihood of immediate irreparable injury ${ }^{150}$ is required in order to obtain a preliminary injunction, and the defendant may take an interlocutory appeal from the grant of a preliminary injunction. ${ }^{151}$

Furthermore, an action such as that in the three FDA caseswhere nearly all the parties affected by a regulation were represented as plaintiffs-may actually serve to speed enforcement: "If the Government prevails, a large part of the industry is bound by the decree; if the Government loses, it can more quickly revise its regulation." 152

Justice Fortas declared: "Experience dictates . . . that it can hardly be hoped that some federal judge somewhere will not be moved as the Court is here, by the cries of anguish and distress of those regulated, to grant a disruptive injunction."'153 Even if Justice Fortas' dire prediction should prove true, it is doubtful that the best way to deal with the problem is to preclude pre-enforcement review of regulations. Congress could very well respond to the problem by limiting venue or restricting review to the courts of appeals in order to assure that preenforcement review would be confined to a court skilled in such actions and astute to the interest of the public, as well as to the needs of the complaining parties.

\section{CONCLUSION}

The Supreme Court has indicated a considerable reluctance to imply congressionally-imposed limitations on access to judicial review of administrative action. At a minimum, there must be clear and convincing evidence in the legislative history of an act that Congress intended to withhold review until a later stage before the courts will hold that the act bars access to judicial review at a given stage of the administrative process.

This does not mean, however, that a party to an administrative proceeding may obtain immediate judicial review anytime he feels that

149. H.E. Fletcher Co. v. Rock of Ages Corp., 326 F.2d 13, 17 (2d Cir. 1963); A.H. Bull Steamship Co. v. National Marine Engineers' Beneficial Ass'n, 250 F.2d 332, 337 (2d Cir. 1957); Hall Signal Co. v. General Ry. Signal Co., 153 F. 907, 903 (2d Cir. 1907).

150. H.E. Fletcher Co. v. Rock of Ages Corp., 326 F.2d 13, 16 (2d Cir. 1963); A.H. Bull Steamship Co. v. National Marine Engineers' Beneficial Ass'n, 250 F.2d 332, 338 (2d Cir. 1957).

151. 28 U.S.C. $\S 1292(a)(1)$ (1964). The courts lave interpreted "injunction" to include preliminary injunctions. Parker v. Columbia Broadcasting Sys., 320 F.2d 937, 938 (2d Cir. 1963); Grant v. United States, 282 F.2d 165, 167 (2d Cir. 1960). Once a court has issued a permanent injunction, the burden is properly on the defendant to obtain a writ of supersedeas if he wishes to be free from restraint pending an appeal. See Brill v. General Indus. Enterprises, Inc., 234 F.2d 465, 469-70 (3d Cir. 1956). See generally Developmens in the Law-Injunctions, 78 HARv. L. REv. 994, $1072-74$ (1965).

152. Abbott Laboratories v. Gardner, 387 U.S. 136, 154 (1967).

153. Gardner v. Toilet Goods Ass'n, 387 U.S. 167, 176 (1967) (dissenting opinion). 
matters are going badly for him. The courts will continue to limit access to judicial review through the application of the ripeness doctrine as incorporated into the review provisions of the Administrative Procedure Act. Unless a plaintiff is clearly entitled to review at the time he seeks it under the provisions of a particular act, the courts will balance the advantages of delaying review until a later stage-clarification of the issues and avoidance of undue interference in the administrative process-against the danger that the plaintiff will be seriously injured by the delay. Where the issues are sufficiently fixed and clear, and where the danger of harm to the plaintiff is such as to make later access to the courts inadequate, the courts will grant review, even though review is normally not available until a later stage of the administrative process.

Although this flexible "ripeness" approach, like any flexible rule, is susceptible to abuse, it is likely to produce far more satisfactory results than an uninhibited judicial search for language implying a statutory preclusion of judicial review. Resort to a rigid solution of the latter type not only prevents the courts from tailoring their grants of review to fit the facts before them, but creates the risk of cutting off meaningful review altogether in unforeseen cases.

A. Keith Lesar 